\title{
Chitosan affects total nutrient digestion and ruminal fermentation in Nellore steers
}

\author{
A.P.C. Araújo ${ }^{a}$, B.C. Venturelli ${ }^{a}$, M.C.B. Santos ${ }^{a}$, R. Gardinal ${ }^{a}$, N.R.B. Cônsolo ${ }^{a}$, \\ G.D. Calomeni ${ }^{a}$, J.E. Freitas ${ }^{\mathrm{a}, 1}$, R.V. Barletta ${ }^{\mathrm{a}}$, J.R. Gandra ${ }^{\mathrm{a}, 2}$, P.G. Paiva ${ }^{\mathrm{b}, *}$, \\ F.P. Rennó ${ }^{\mathrm{a}}$ \\ a Department of Animal Nutrition and Production, School of Veterinary Medicine and Animal Science, University of São Paulo (USP), \\ Avenue Duque de Caxias Norte, 225-Campus da USP, 13635-900 Pirassununga, SP, Brazil \\ b Departement of Animal Science, UNESP - Universidade Estadual Paulista “Júlio de Mesquita Filho"/Campus Jaboticabal, Rod. Prof. \\ Paulo Donato Castellane, km 5, Rural, 14884-900 Jaboticabal, SP, Brazil
}

\section{A R T I C L E I N F O}

\section{Article history:}

Received 6 October 2014

Received in revised form 26 May 2015

Accepted 27 May 2015

\section{Keywords:}

Beef cattle

Blood parameters

Chitosan

Digestibility

Intake

Ruminal fermentation

\begin{abstract}
A B S T R A C T
This study aimed to investigate the effects of chitosan on dry matter intake (DMI), nutrient digestibility, ruminal fermentation, and blood metabolites in Nellore steers. Eight ruminally cannulated Nellore steers ( $540 \pm 28.5 \mathrm{~kg}$ of BW) were used in a replicated $4 \times 4$ Latin square design, with 21-d of experimental periods. The animals were randomly assigned to the following treatments: control (without chitosan addition; Q0), Q50, Q100 and Q150, by dosing 50,100 and $150 \mathrm{mg} / \mathrm{kg}$ BW chitosan, respectively, through the cannula. Although there was no difference on DMI, chitosan addition increased dry matter, neutral detergent fiber, and crude protein apparent total-tract digestibility $(P<0.05)$. Ruminal $\mathrm{pH}$ was not affected, whereas $\mathrm{NH}_{3}-\mathrm{N}$ concentration was quadratically affected with chitosan addition $(P=0.01)$. There were no differences in total volatile fatty acids concentration among treatments. Chitosan had a quadratic effect on propionate and butyrate, whereas acetate molar proportions decreased linearly $(P<0.05)$. Acetate:propionate ratio decreased with chitosan addition $(P<0.05)$. Plasma glucose concentration was higher with chitosan addition $(P<0.05)$; however, total protein, urea, aspartate aminotransferase, and gamma-glutamyl transferase were not affected by chitosan. Addition of chitosan altered ruminal fermentation, improved nutrient digestibility, and did not appear to damage animal health.
\end{abstract}

(c) 2015 Elsevier B.V. All rights reserved.

\section{Introduction}

Chitosan is one of the most abundant natural polysaccharide biopolymers. It is obtained by deacetylation of chitin, which is found in the exoskeleton of insects and crustaceans; due to its characteristics, such as biodegradability and nontoxicity, chitosan has received much attention due to its potential antimicrobial properties against bacteria, fungi, and yeasts (Kong et al., 2010).

Abbreviations: ADF, acid detergent fiber; DM, dry matter; DMI, dry matter intake; OM, organic matter; CP, crude protein; EE, ether extract; aNDF, neutral detergent fiber with residual ash; NFC, non-fiber carbohydrate; VFA, volatile fatty acids.

* Corresponding author. Tel.: +55 1935654248 ; fax: +55 1935654368.

E-mail addresses: bocazoo@hotmail.com (P.G. Paiva), francisco.renno@usp.br (F.P. Rennó).

1 Present address: Department of Animal Science, Federal University of Bahia, Salvador, BA 40170-110, Brazil.

2 Present address: Department of Animal Science, Universidade Federal da Grande Dourados, Dourados, MS 79804-970, Brazil. 
Table 1

Ingredient and nutrient composition of diet.

\begin{tabular}{|c|c|}
\hline Item & Diet \\
\hline \multicolumn{2}{|l|}{ Ingredient composition (g/kg DM) } \\
\hline Corn silage $^{\mathrm{a}}$ & 600.0 \\
\hline Ground corn & 287.0 \\
\hline Soybean meal & 48.5 \\
\hline Whole raw soybean & 39.9 \\
\hline Urea & 4.8 \\
\hline Ammonium sulfate & 2.0 \\
\hline Limestone & 0.9 \\
\hline Mineral premix ${ }^{b}$ & 16.0 \\
\hline Salt & 0.9 \\
\hline \multicolumn{2}{|l|}{ Chemical composition (g/kg DM) } \\
\hline Dry matter (g/kg) & 513.5 \\
\hline Organic matter & 933.1 \\
\hline Crude protein & 137.8 \\
\hline Neutral detergent fiber (aNDF ${ }^{c}$ & 386.4 \\
\hline Non-fiber carbohydrate ${ }^{\mathrm{d}}$ & 376.3 \\
\hline Ether extract & 32.6 \\
\hline Net energy $^{\mathrm{e}}(\mathrm{MJ} / \mathrm{kg})$ & 6.77 \\
\hline \multicolumn{2}{|c|}{ a Nutrient composition (g/kg DM): 261.9 DM; 91.8 CP; 577.2 aNDF and 246.7 NFC. } \\
\hline \multirow{2}{*}{\multicolumn{2}{|c|}{$\begin{array}{l}\text { Zn: } 2500 \mathrm{mg} \text {; Mn: } 1000 \mathrm{mg} \text {; I: } 80 \mathrm{mg} \text {; Co: } 100 \mathrm{mg} \text {; Se: } 20 \mathrm{mg} \text {. } \\
\text { c aNDF, neutral detergent fiber with residual ash. }\end{array}$}} \\
\hline & \\
\hline \multicolumn{2}{|c|}{ of $\mathrm{NDF}+\mathrm{g} / \mathrm{kg}$ of $\mathrm{EE}+\mathrm{g} / \mathrm{kg}$ of ash) Hall (2000). } \\
\hline
\end{tabular}

Although chitosan has application in different areas (food, pharmaceutical, and cosmetics), its use as an additive in ruminant nutrition has not been extensively investigated, with a small number of studies reporting conflicting results. In in vitro assays, inclusion of chitosan changed ruminal fermentation parameters, reflected by elevated propionate concentration (Goiri et al., 2009a,b); but in these studies, chitosan decreased digestibility of dry matter (DM) and neutral detergent fiber (NDF). On the other hand, when added to the diet of sheep, chitosan increased propionate proportion without affecting OM digestibility (Goiri et al., 2010). Thus, chitosan might alter ruminal fermentation for more energetically efficient patterns and may provide an alternative to antimicrobial growth promoters (Goiri et al., 2009a,b, 2010); nevertheless, more in vivo studies are necessary to identify the effect of chitosan on ruminal fermentation. Therefore, this study was aimed to evaluate the effects of chitosan on dry matter intake (DMI), nutrient digestibility, ruminal fermentation and blood metabolites in Nellore steers.

\section{Materials and methods}

Experimental procedures were approved by the Animal Use Ethics Commission of the School of Veterinary Medicine and Animal Science (protocol number 2222/2011), University of São Paulo, Brazil.

\subsection{Animals and experimental treatments}

Eight ruminally cannulated Nellore steers ( 24 month old; $540 \pm 28.5 \mathrm{~kg}$ of BW) were used in a replicated $4 \times 4$ Latin square design, with 21-d experimental periods, with $14 \mathrm{~d}$ of adaptation to treatments and $7 \mathrm{~d}$ of sampling. The animals were kept in confinement in covered, individual tie-stall barns. Chitosan used in this assay had the following technical specifications: apparent density $0.64 \mathrm{~g} / \mathrm{mL}$; total ash $\leq 2.0 \%$; $\mathrm{pH} 7.0-9.0$; viscosity <200 cPs; and degree of deacetylation > 92\% (Polymar Indústria e Comércio Importação e Exportação LTDA, Fortaleza, Ceará, Brazil).

The Nellore steers were randomly assigned to the following experimental treatments: (Q0), without chitosan addition; or Q50, Q100 and Q150, with addition of 50, 100 and $150 \mathrm{mg} / \mathrm{kg}$ BW chitosan, respectively. The amount of chitosan provided to each animal was weighed daily into paper bags, divided equally into two portions and placed directly in the rumen through the cannula, twice daily, in the morning and in the afternoon before feeding. Steers were fed twice daily at 0700 and $1400 \mathrm{~h}$, and the feed offered was adjusted daily to yield 5-10\% orts. Experimental diet was formulated according to the NRC (2000) to allow approximately $1.20 \mathrm{~kg} / \mathrm{d}$ body weight gain and was provided as total mixed ration (TMR; Table 1 ).

\subsection{Data collection and analysis}

Feed intakes were recorded daily as the difference between feed offered and refused. During sampling periods, individual feed and orts sample (about $0.5 \mathrm{~kg}$ ) were taken daily, pooled by steers for each sampling period and stored at $-20^{\circ} \mathrm{C}$. Samples of feed and orts were dried in a $55^{\circ} \mathrm{C}$ forced-air oven for $72 \mathrm{~h}$, ground to pass through a $1 \mathrm{~mm}$ screen (Wiley Mill, A.H. Thomas, 
Philadeilphia, PA) and then analyzed for dry matter (method 930.15; AOAC, 2000), ash (method 942.05; AOAC, 2000), ether extract (method 920.39; AOAC, 2000), and crude protein $(\mathrm{N} \times 6.25$; method 984.13, AOAC, 2000). Neutral detergent fiber (aNDF) was analyzed according to the technique described by Mertens (2002), with addition of heat-stable alpha-amylase but without the addition sodium sulfite to the detergent (Ankom Tech. Corp., Fairport, NY) and the result was expressed with residual ash.

On d 15-18 of each period, feces samples $(0.5 \mathrm{~kg})$ were taken from each steer at 0800 and $1600 \mathrm{~h}$ directly from the rectum, pooled by steers for each period and indigestible acid detergent fiber (iADF) was used as an internal marker to estimate fecal excretion and apparent total tract digestibility of nutrients. Feeds, orts and feces samples were dried in a $55^{\circ} \mathrm{C}$ forced-air oven for $72 \mathrm{~h}$ and ground to pass through $2 \mathrm{~mm}$ screen (Wiley mill, A.H. Thomas, Philadelphia, NY), and then were placed into $4 \mathrm{~cm} \times 5 \mathrm{~cm}$ F57 Ankom filter bags $\left(20 \mathrm{mg}\right.$ of DM/ $\mathrm{cm}^{2}$ ) that had previously been weighed. These samples were incubated for $264 \mathrm{~h}$ in the rumen of two Nellore steers previously adapted to similar experimental diet according with technique described by Casali et al. (2008). After incubation, bags were removed and washed in running water, and then analyzed for ADF concentration as described Van Soest et al. (1991) using Ankom ${ }^{\circledR}$ System (Ankom Tech. Corp., Fairport, NY). Apparent total tract digestibility was calculated using the ratio of iADF in feed (corrected for orts) and feces.

\subsection{Ruminal fermentation parameters}

Ruminal fluid samples were collected before (0) and 2, 4, 6, 10 and $12 \mathrm{~h}$ after the morning feeding on $\mathrm{d} 15$ of each period. The ruminal pH values were determined using a digital pH meter (MB-10, Marte Científica, Minas Gerais, Brazil). Aliquots of samples were mixed with metaphosphoric acid $\left(0.25 \mathrm{~mol} / \mathrm{L} \mathrm{HPO}_{3}\right)$, and then centrifuged at $7000 \times g$, and supernatant stored at $-20^{\circ} \mathrm{C}$ for analysis of volatile fatty acids (VFA). The remaining aliquots of samples were mixed with sulfuric acid ( $0.5 \mathrm{~mol} / \mathrm{L}$ $\mathrm{H}_{2} \mathrm{SO}_{4}$ ) and stored at $-20^{\circ} \mathrm{C}$ for determination of ammonia nitrogen $\left(\mathrm{NH}_{3}-\mathrm{N}\right)$ concentration of according to the colorimetric method adapted by Foldager (1977). Ruminal VFA were measured with a gas chromatograph (GC-2014, Shimadzu, Tokio, Japan) equipped with a capillary column (Stabilwax, Restek, Bellefonte, EUA). The gases used in the analyses were helium $(8.01 \mathrm{~mL} / \mathrm{min}$ flow) as carrier gas, hydrogen (pressure of $60 \mathrm{kPa}$ ) as fuel gas, and synthetic air (pressure of $40 \mathrm{kPa}$ ) as oxidizer gas. The steamer temperature was set at $220^{\circ} \mathrm{C}$, the ionization detector flames at $250^{\circ} \mathrm{C}$, and the separation column at $145^{\circ} \mathrm{C}$ for $3 \mathrm{~min}$, which was then, raised $10^{\circ} \mathrm{C} / \mathrm{min}$ up to $200^{\circ} \mathrm{C}$.

\subsection{Blood metabolites}

On d 18 of each period, blood samples were collected before the morning feeding from coccygeal vein using an evacuated tube with anticoagulant (EDTA). Samples were centrifuged at $2000 \times g$ for $15 \mathrm{~min}$. Commercial Laborlab kits (Laborlab, Guarulhos, São Paulo, Brazil) were used for analyses of glucose, total protein, plasma urea nitrogen, aspartate aminotransferase (AST), and gamma-glutamyl transferase (GGT) using an automatic biochemistry analyzer (Model-SBA-200, Modern Laboratory Equipment Company, São Paulo, Brazil).

\subsection{Statistical analysis}

Data were analyzed with PROC MIXED (SAS Inst. Inc., Cary, NC), as a $4 \times 4$ Latin square design according to the model: $Y_{i j k}=\mu+S_{i}+P_{j}+T_{k}+e_{i j k}$; where $Y_{i j k}=$ dependent variable; $\mu=$ overall mean; $S_{i}=$ random effect: $\operatorname{steer}(i=1-8)$; $P_{j}=$ fixed effect: period $(j=1-4) ; T_{k}=$ fixed effect: treatment $(k=1-4)$; and $e_{i j k}=$ residual error.

Ruminal fermentation characteristics (VFA, $\mathrm{pH}, \mathrm{NH}_{3}-\mathrm{N}$ ) were analyzed with repeated measures by added sampling time ( 0 (before) and $2,4,6,8,10$ or $12 \mathrm{~h}$ after-morning feeding) to the previous model. First-order autoregressive covariance structure [AR (1)] was used for data analysis based upon the smallest Akaike's information criterion values. Other covariance structures tested included compound symmetry, heterogeneous compound symmetry and unstructured. Responses to chitosan inclusion levels were tested with linear and quadratic contrasts, which were declared significant at $P<0.05$.

\section{Results}

There was no effect of chitosan concentration on DMI $(P>0.05)$, either in absolute value $(\mathrm{kg} / \mathrm{d})$ or relative to body weight (g/100 g of BW; Table 2). Apparent total tract digestibility of DM, CP and NDF increased with chitosan addition in the rumen $(P<0.05)$, although EE digestibility was similar among treatments $(P>0.05)$. Plasma total protein, urea, and liver enzymes AST and GGT were not influenced by chitosan addition in the rumen $(P>0.05)$; however, glucose levels increased linearly with chitosan addition $(P=0.01)$.

Ruminal pH was not affected by treatment $(P>0.05)$; however, chitosan inclusion $(50,100,150 \mathrm{mg} / \mathrm{kg}$ of BW) caused quadratic effects on $\mathrm{NH}_{3}-\mathrm{N}$ concentration in the ruminal fluid $(P=0.01$; Table 3$)$. There were no differences in total VFA concentration in the ruminal fluid $(P>0.05)$ with the chitosan addition in the rumen. Nevertheless, chitosan inclusion was associated with a linear decrease in acetate $(P=0.01)$ and a quadratic effect in propionate $(P=0.01)$ and butyrate $(P=0.04)$ molar proportions $(\mathrm{mmol} / 100 \mathrm{~mol})$. This resulted in a quadratic effect on acetate:propionate ratio $(P=0.03)$. 
Table 2

Effects of chitosan on DMI, apparent total tract digestibility of nutrients and blood metabolites in Nellore steers.

\begin{tabular}{|c|c|c|c|c|c|c|c|}
\hline \multirow[t]{2}{*}{ Item } & \multicolumn{4}{|c|}{ Treatment $^{\mathrm{a}}$} & \multirow[t]{2}{*}{ SEM } & \multicolumn{2}{|c|}{$P$-value ${ }^{b}$} \\
\hline & Q0 & Q50 & Q100 & Q150 & & LIN & QUA \\
\hline \multicolumn{8}{|l|}{ Intake } \\
\hline Dry matter (kg/d) & 8.26 & 8.49 & 8.39 & 8.25 & 0.16 & 0.87 & 0.30 \\
\hline Dry matter $(\mathrm{g} / 100 \mathrm{~g}$ of $\mathrm{BW})$ & 1.48 & 1.54 & 1.52 & 1.49 & 0.02 & 0.97 & 0.25 \\
\hline \multicolumn{8}{|l|}{ Digestibility ( $\mathrm{g} / \mathrm{kg}$ of DM) } \\
\hline Dry matter & 646 & 675 & 683 & 690 & 7.3 & 0.02 & 0.35 \\
\hline Crude protein & 631 & 649 & 664 & 675 & 8.1 & 0.04 & 0.79 \\
\hline Ether extract & 803 & 802 & 802 & 838 & 15.3 & 0.29 & 0.39 \\
\hline Neutral detergent fiber (aNDF) & 566 & 601 & 606 & 605 & 7.2 & 0.04 & 0.17 \\
\hline \multicolumn{8}{|l|}{ Blood metabolites } \\
\hline Glucose (mg/dL) & 54.3 & 64.6 & 68.5 & 67.2 & 2.21 & 0.01 & 0.08 \\
\hline Total protein $(\mathrm{mg} / \mathrm{dL})$ & 51.2 & 51.2 & 65.6 & 61.5 & 0.37 & 0.18 & 0.78 \\
\hline Urea $(\mathrm{mg} / \mathrm{dL})$ & 30.3 & 30.3 & 32.2 & 29.1 & 1.70 & 0.87 & 0.55 \\
\hline $\operatorname{AST}^{c}(U / L)$ & 55.7 & 65.5 & 52.0 & 58.0 & 3.20 & 0.80 & 0.75 \\
\hline $\mathrm{GGT}^{\mathrm{d}}(\mathrm{U} / \mathrm{L})$ & 4.2 & 3.2 & 2.8 & 3.2 & 0.23 & 0.07 & 0.10 \\
\hline
\end{tabular}

a Q0, control treatment; Q50, Q100 and Q150 = 50, 100 and $150 \mathrm{mg} / \mathrm{kg}$ BW chitosan put into the rumen through the cannula.

b LIN, linear and QUA, quadratic effect of treatment.

c AST, aspartate aminotransferase.

d GGT, gamma-glutamyl transferase.

\section{Discussion}

In this study, we aimed to evaluate the effects of chitosan levels on DMI and nutrient metabolism in Nellore steers. We observed a linear increase in DM and NDF digestibility with chitosan addition in the rumen without effect on DMI (7\% increase from diets Q0 to Q150), probably related to altered ruminal fermentation. However, Goiri et al. (2009b) showed in vitro conditions that chitosan lowered NDF digestibility. In a study with sheep, chitosan tended to decrease NDF digestibility but without reducing OM digestibility (Goiri et al., 2010). One factor that may cause a reduction in NDF digestibility is the reduction in ruminal $\mathrm{pH}$ values which results in depressed fermentation activity of the fibrolytic population (Hoover, 1986; Calsamiglia et al., 2002). However, in the present study there was no effect of chitosan levels on ruminal pH (6.3 \pm 0.02 ; mean \pm SEM).

Chitosan supplementation changed molar $\mathrm{C} 2: \mathrm{C} 3$ ratio in the rumen without reducing total VFA concentration. Lower C2:C3 ratio has already been reported in response to chitosan (Goiri et al., 2009a,b, 2010). This increase in propionate (7\%) and reduction in acetate (2\%) proportion can be associated with changes in the carbohydrate digestion without altering DMI when chitosan was added in the rumen. Moreover, this response is consistent with increasing in glucose concentration (20\%) with chitosan inclusion. Antibacterial activity of chitosan is a complicated process that differs between Gram-positive and Gram-negative bacteria (Kong et al., 2010). Chung et al. (2004) reported that chitosan has stronger antibacterial activity in Gram-negative than Gram-positive bacteria, while Zhong et al. (2008) indicated that Gram-positive bacteria were more susceptible to derivatives of chitosan, likely as a consequence of the Gram-negative outer membrane barrier. $\mathrm{pH}$ is another important factor for antibacterial activity of chitosan. According Kong et al. (2010) when pH is below the chitosan $\mathrm{p} K_{\mathrm{a}}$, electrostatic interaction between the polycationic structure and anionic components of the microorganism's surface (such as Gram-negative lipopolysaccharide and cell surface proteins) plays a major role in antibacterial activity. This is because chitosan molecule becomes polycationic as $\mathrm{pH}$ below the molecule's $\mathrm{p} K_{\mathrm{a}}(6.3-6.5)$ (Lim and Hudson, 2004). On the other

Table 3

Effects of chitosan on ruminal fermentation parameters in Nellore steers.

\begin{tabular}{|c|c|c|c|c|c|c|c|c|c|}
\hline \multirow[t]{2}{*}{ Item } & \multicolumn{4}{|c|}{ Treatment $^{\mathrm{a}}$} & \multirow[t]{2}{*}{ SEM } & \multicolumn{4}{|c|}{$P$-value ${ }^{\mathrm{b}}$} \\
\hline & Q0 & Q50 & Q100 & Q150 & & TRT & TRT $\times$ TIME & LIN & QUA \\
\hline $\mathrm{pH}$ & 6.3 & 6.3 & 6.3 & 6.3 & 0.02 & 0.71 & 0.77 & 0.64 & 0.90 \\
\hline $\mathrm{NH}_{3}-\mathrm{N}(\mathrm{mg} / \mathrm{dL})$ & 15.4 & 18.1 & 17.6 & 15.6 & 0.52 & 0.10 & 0.99 & 0.99 & 0.01 \\
\hline Total VFA (mM) & 105.9 & 105.7 & 106.2 & 103.7 & 2.48 & 0.66 & 0.63 & 0.39 & 0.45 \\
\hline \multicolumn{10}{|l|}{$\mathrm{VFA}(\mathrm{mol} / 100 \mathrm{~mol})$} \\
\hline Acetate & 69.1 & 69.0 & 68.6 & 67.9 & 0.33 & $<0.01$ & 0.98 & $<0.01$ & 0.12 \\
\hline Propionate & 19.6 & 19.5 & 20.2 & 21.1 & 0.32 & $<0.01$ & 0.99 & $<0.01$ & 0.01 \\
\hline Butyrate & 11.1 & 11.4 & 11.1 & 10.8 & 0.18 & 0.02 & 0.98 & 0.04 & 0.04 \\
\hline $\mathrm{C} 2: \mathrm{C}^{\mathrm{C}}$ & 3.5 & 3.5 & 3.4 & 3.2 & 0.07 & $<0.01$ & 0.97 & $<0.01$ & 0.03 \\
\hline
\end{tabular}

a Q0, control treatment; Q50, Q100 and Q150 =50, 100 and $150 \mathrm{mg} / \mathrm{kg}$ BW chitosan put into the rumen through the cannula.

b Effect of treatment (TRT); interaction treatment $\times$ hours after feed (TRT $\times$ TIME); LIN, linear, and QUA, quadratic effect of treatment.

c Acetate:propionate ratio. 
hand, hydrophobic and chelating effects are responsible for antibacterial activity of chitosan when the environment pH is above $\mathrm{p} K_{\mathrm{a}}$ (Kong et al., 2010). Furthermore, increase in propionate and changes in final fermentation products in the present study suggested the effect on Gram-positive bacteria (McGuffey et al., 2001).

Chitosan inclusion resulted in quadratic effects on $\mathrm{NH}_{3}-\mathrm{N}$ concentration in the ruminal fluid, which may be associated with increased CP total-tract digestibility with chitosan addition in the rumen and lower protein degradation in the Q150 treatment. Goiri et al. (2010) also reported that chitosan inclusion ( $136 \mathrm{mg} / \mathrm{kg}$ of BW) decreased ruminal fluid $\mathrm{NH}_{3}-\mathrm{N}$ concentration compared with control treatment, likely associated with decrease in ruminal amino acid degradation, but without effect on CP total-tract digestibility. The maintenance of normal blood urea levels is essential to reduce energy expense with $\mathrm{N}$ excretion in the urine. Moreover, changes in plasma urea levels may be directly associated with feed consumption (Quigley and Bernard, 1992; Moscardini et al., 1998), which was not observed effect in this study. Conversely, Garcia-Rodriguez et al. (2011) related an $8.9 \%$ increase in blood urea of sheep supplemented with chitosan (137 mg/kg of BW) during lactation, which may be associated with a more protein degradability in the rumen and reduction of microbial protein synthesis. Liver enzymes (AST and GGT) and total protein may be used as indicators of metabolic and health status. In the present study these values are within normal range (Kaneko et al., 1997) and were not influenced by inclusion of chitosan.

\section{Conclusion}

Chitosan can be used as an additive modulator of rumen fermentation because its capability to improve nutrient digestibility and propionate concentrations, especially chitosan levels between 100 and $150 \mathrm{mg} / \mathrm{kg}$ of body weight.

\section{Conflict of interest}

None of the authors of the above manuscript has declared any conflict of interest statement.

\section{Acknowledgements}

The authors would like to thank FAPESP for financial support (grant \# 2011/01967-7); Barry Bradford and Abigail Carpenter at Kansas State University (Manhattan, KS) for your review and comments in this article.

\section{References}

AOAC (Association of official Analytical Chemists), 2000. Official Methods of Analysis, 17th ed. AOAC International, Arlington, VA.

Calsamiglia, S., Ferret, A., Devant, M., 2002. Effects of pH and pH fluctuations on microbial fermentation and nutrient flow from a dual-flow continuous culture system. J. Dairy Sci. 85, 574-579.

Casali, A.O., Detmann, E., Valadares Filho, S.C., Pereira, J.C., Henriques, L.T., Freitas, S.G., Paulino, M.F., 2008. Influence of incubation time and particles size on indigestible compounds contents in cattle feeds and feces obtained by in situ procedures. Rev. Bras. Zootec. 37, 335-342.

Chung, Y.C., Su, Y.P., Chen, C.C., Jia, G., Wang, H.L., Wu, J.C.G., Lin, J.G., 2004. Relationship between antibacterial activity of chitosans and surface characteristics of cell wall. Acta Pharmacol. Sin. 25, 932-936.

Foldager, J., 1977. Protein Requirement and Non-Protein Nitrogen for High Producing Cow in Early Lactation. Michigan State University, East Lasing, MI (Ph.D. diss).

Garcia-Rodriguez, A., Mandaluniz, N., Arranz, J., Goiri, I., 2011. Inclusion of chitosan in the diet of dairy ewes in early lactation. In: Asociación Interprofesional para el Desarrollo Agrario. XIV Jornadas sobre Producción Animal, Zaragoza, España, pp. 222-224.

Goiri, I., Garcia-Rodriguez, A., Oregui, L.M., 2009b. Effect of chitosan on mixed ruminal microorganism fermentation using the rumen simulation technique (Rusitec). Anim. Feed Sci. Technol. 152, 92-102.

Goiri, I., Oregui, L.M., Garcia-Rodriguez, A., 2009a. Dose-response effects of chitosans on in vitro rumen digestion and fermentation of mixtures differing in forage-to-concentrate ratios. Anim. Feed Sci. Technol. 151, 215-227.

Goiri, I., Oregui, L.M., Garcia-Rodriguez, A., 2010. Use of chitosans to modulate ruminal fermentation of 50:50 forage-to-concentrate diet in sheep. J. Anim. Sci. 88, 749-755.

Hall, M.B., 2000. Calculation of Non-Structural Carbohydrate Content of Feeds that Contain Non-Protein Nitrogen. University of Florida, p.A.-25 (Bulletin 339).

Hoover, W.H., 1986. Chemical factors involved in ruminal fiber digestion. J. Dairy Sci. 69, 2755-2766.

Kaneko, J.J., Harvey, J.W., Bruss, M., 1997. Appendices. In: Kaneko, J.J., Harvey, J.W., Bruss, M. (Eds.), Clinical Biochemistry of Domestic Animals. , 5th ed. Academic Press, San Diego, pp. 885-905.

Kong, M., Chen, X.G., Xing, K., Park, H.J., 2010. Antimicrobial properties of chitosan and mode of action: a state of the art review. Int. J. Food Microbiol. 144, $51-63$.

Lim, S.H., Hudson, S.M., 2004. Synthesis and antimicrobial activity of a water-soluble chitosan derivative with a fiber-reactive group. Carbohydr. Res. 339 313-319.

McGuffey, R.K., Richardson, L.F., Wilkinson, J.I.D., 2001. Ionophores for dairy cattle: current status and future outlook. J. Dairy Sci. 84, E194-E203.

Mertens, D.R., 2002. Gravimetric determination of amylase-treated neutral detergent fiber feeds with refluxing in beakers or crucibles: collaborative study. J. AOAC Int. 85, 1217-1240.

Moscardini, S., Wright, T.C., Luimes, P.H., McBride, B.W., Susmel, P., 1998. Effects of rumen-undegradable protein and feed intake on purine derivate and urea nitrogen: comparison with predictions from the Cornell Net Carbohydrate and Protein System. J. Dairy Sci. 81, 2421-2429.

NRC National Research Council, 2000. Nutrient Requirements of Beef Cattle, 7th ed. Natl. Acad. Press, Washington, DC.

Quigley, J.D., Bernard, J.K., 1992. Effect of nutrient source and time of feeding on changes in blood metabolites in young calves. J. Anim. Sci. 70, 1543-1549.

Van Soest, P.J., Robertson, J.B., Lewis, B.A., 1991. Methods for dietary fiber, neutral detergent fiber, non-starch polysaccharides in relation to animal nutrition. J. Dairy Sci. 74, 3583-3597.

Zhong, Z.M., Xing, R.G., Liu, S., Wang, L., Cai, S.B., Li, P.C., 2008. Synthesis of acyl thiourea derivatives of chitosan and their antimicrobial activities in vitro. Carbohydr. Res. 343, 566-570. 